\title{
Increased Capacity Village Officials About Governance Administration In Of The Village Administration
}

\author{
Siti Hajar \\ Doctoral Program of Public Administration \\ Universitas Brawijaya, Indonesia (Student BUDI-DN) \\ Universitas Muhammadiyah Sumatra Utara, Indonesia \\ sitihajar4416@gmail.com
}

\begin{abstract}
The increased capacity village officials about governance administration to embody professional government, creative, efficient is an activity that support the development of the ability village officials in managing village administration. Administration done by village administration Selemak, have not optimal and perfect. This is caused by lack of the ability village officials in manage the administration of well and correctly, do not know well on elements administration so overlap the implementation of the duty and function as an administrator public. The implementation of the increased capacity village officials about governance administration was conducted with the counselling methods, discussion and duty. This activity is carried out by providing training governance administration that would give and directing the administration in the village administration. Training governance administration is also aimed to improve the ability village officials in manage budgets and files related in fund village budget.
\end{abstract}

Keyword: governance administration and village administration

\section{INTRODUCTION}

Commonly, administration conducted by Village Government is not optimal and perfect. This is caused by the lack of ability of village officials in administering the program properly, and do not know well about the elements of the administration so as happened overlapping duties and functions as a public administrator.

To support the administration of village government with good and right, can to do through efforts to improve the ability of village officials in the administration management. This effort is expected to be a motivation for village officials to doing effective administration management to achieve, professional, creative, effective and efficient government.

Based on the results of research conducted by [1], that the Village Government especially in Selemak Village, requires improvement human resource (village officials) to manage the village administration. This is because village officials is one of the public administrator in charge of village governance to serve the country and serve the community.

Village officials also called administrator who has a function in organizing the village administration. [2] suggests that the functions of the administrator are: 1) Implement the overall administration of the organization; 2) Conducting commercial activities to make the organization more advance in terms of income and capital wealth, buying and selling, leasing and so on; 3) Running the production activities, improve quality of technology and product of services and goods, 4) Perform financial activities, both in the sense of seeking funds for investment and shopping as well as the management of funds, including financing, 5) Develop and enforce compatibility, it means running and developing all effort to use everything have been obtained.

Lack of ability in carrying out the duties and functions as a public servant, cause not optimal of the administration management in the village especially in Selemak Village. So, its needed to takes trainings related to the administration management program to improve special ability of village officials.

A problem to be solved by improving village officials is improve the ability of village officials about administration management related to the introduction of elements of administration include organizing, management, relationship management, finance, supplies, administration and representation.

Improving the ability of village officials on administration management aims; 1) Provide the knowledge and skills to manage the administration related to elements administration to achieve good governance; 2) Helping village government to perform well administrative management that focused on the elements of the administration resulting in effective performance.

\section{REVIEW OF LITERATURE}

Administration activities are performed by the administrator (village officials) is one of the key success in managing the organization one of the implementation is village government. The key to success in the implementation of 
good governance is influenced by several factors, according to a study conducted by the [3], namely:

1. Leadership Commitment.

Consistency is of highest leadership in the area who earnestly implement governance management in the region. Leaders serve as the driving form of change and become a pioneer in the implementation.

2. The Strong Legal Basis

Each implementation of policies for improving the good governance system, must have a strong legal basis, either in the form of Regulations or Decisions. In the framework of a policy of sustainability that good governance should be the legal basis used is local regulation so that despite the change of leadership of the region, the policy will still be running.

3. Supported from the internal environment and society

The support on innovation policy of good management governance is necessary because the policy is created, managed and reserved for them.

4. Internal Initiatives.

The supported for new ideas / initiatives to improve the system of governance ideally come from the ideas of employees or internal leadership within the scope of the government concerned. Repair system based on persuasion and discussion by local wisdom makers, and then communicated to the entire staff will resulted higher support and commitment for the staff entire.

[2] suggested that the administrator is leading an administration or organization unit, responsible to the owner who given the duty, obligation, and directives. The administrator duties, are: 1) The administrator should take control and understanding the mission (the basic tasks ) enterprise as the owners desire in the organization, other provisions; 2) The administrator is drafting everything what the entrepreneurs want and decision, act on the name of business entity, into a form that can be understood concretely by subordinates and can be implemented in the real; 3) The administrator is to maintain and develop the organization that given to him as precisely as possible, especially in the sense of personal discipline, orderly material, functional, orderly authority and responsibility. For that, the administrator must master the subtleties of the organization, both theoretically and practically; 4) The administrator is to maintain and develop an information system in a good way, including accounting systems, inventory systems, filing systems, documentation systems and communication systems; 5) The administrator is to maintain and develop management systems that precisely as possible both in terms of personal and processual; 6) The administrator duty is to make all the goal and purpose of the enterprise is achieved with material and spiritual profit as well as possible for business entities.

According [4], the term good management governance is also called good governance, and has three parts, namely economic, political and administrative. Economic governance includes decision-making process that facilitating equity, poverty and quality or the life. Political governance is the decision-making process for policy formulation.
Administrative governance is the process implementation system of the policy.

[5], suggests that the government is an organization or a space of people who have the power and the institutions that caring about the state and welfare of the people and also the state. [6] points out the functions of the village governance, namely: 1) Organize rural household affairs; 2) Implement development and social development; 3) Implement the participation and self development of mutual aid societies; 4) Implement fostering peace and public order; 5) Implement economic development of the village; 6) Implement the dispute settlement deliberations; 7) And so forth.

\section{EXECUTION METHOD}

The Implementation of increased the ability of village officials about governance administration is done with counselling method, discussions and assignments. counselling methods done by giving explanation about the administration on the organization of the village governance. Besides that, it was also given the material and explanations about the utilization of the administration at the village level, and given understanding about the implementation of political activities at the village level in the activities of government and development.

Method of discussion is to give the opportunity to participants training improvement the ability of village officials about management governance to questioning and problems solving that become obstacles in the administration. While the task method is done by filling out a questionnaire relating to the administration of the village. Finally, the results would be material, especially recommendations for the improvement of village governance.

\section{RESULTS}

Develop the administration governance that focused on the elements of the management resulting in administrative management to realize good governance through increase the ability of village officials about the governance administration. The program to improve the governance administration was followed by 16 participants consisting of the entire village government officials including members of the Village Consultative Body (BPD) Selemak Village. The trainee's only a few people were educated S1 is 3 and the rest of high school graduates.

Today, administrative management by the village officials still manually, although the system has been using computers in any matters required by society. However, in financial administration field is still a lack of knowledge of the village officials so it needed financial expert especially for village fund budget program by the government through the implementation of Law No. 6 of 2014 About the Village.

Administration of the village governance is needed personnel skilled in the administration because the government must be related to the administration. The Implementation of increasing management administrative ability to village governance is done through the provision of counselling, discussions and assignments that given by an experts who are 
competent in their fields, including: administration experts, budget management and ordinances provide administrative services.

Based on the results of the research obtained, all participant given tasks that related to the administration management so that the participants (village officials) who receive training can truly understand and master the governance administration. Thought this even, it can be seen that the ability of village officials in the Selemak Village is still low. These results were obtained after discussion and tasks assigned given to the participants by the experts.

Assessment in this activity is point out by giving the task after receiving guidance and counselling that given by experts and then discussed as resource materials to accomplish the tasks of administrative governance. This activity is expected to increase the knowledge of village officials in village administration, so the administration in Selemak Village can be arranged.

The implementation of increase village officials ability about the administration, provides some benefits, they are: 1) Increased village officials knowledge and ability in administrative management thus ensuring good governance; 2) Able to use the elements of village administration in village governance; 3) Increased knowledge in the development activities improved the ability of village officials about the management administrative to government agencies.

\section{CONCLUSION}

Administration at the village level is very important because by the administration then the archives and documents can be saved orderly. Thus, the administration must be managed properly by people who know well about the administrative management.

Increased knowledge about the governance administration can be done thought training activities that support increasing the ability of village officials in governance administration. One of the village who conduct this training activities are Selemak Village. The training has been implemented to provide material that could improve understanding of village officials in administering the program at the village level.

The suggestion given as follows; 1) This activity should be a work program of village governance, especially Selemak Village, as an effort to increase village official ability in all areas. ; 2) It need the motivation from the leadership of the district and village leaders to support the village official to continue their studies at a higher level.

\section{REFERENCES}

[1] Tanjung, Irwan Syari dan Hajar, Siti. Public Service Quality Improvement Through Total Quality Model Application Service (TQS) in the District Government Hamparan Perak Village. Higher Education Research Grants: University Muhammadiyah North Sumatra, 2015.

[2] Anggara, Sahya. Public Administration, Faithful Reader: Bandung, 2012.

[3] Corruption Eradication Commission. Implementation of Good Governance. Directorate of Research and Development: Jakarta, 2006.

[4] Syafri, Wirman. Studies in Public Administration, Erlangga: Jakarta, 2014.

[5] Sihabudin, Aan Anwar (2010) The Influence of the Implementation Function of Consultative Board (BPD) againts The Effectiveness of Work Performance of Village Administration (Case Study at Village Office Kertaharja the District Cijengjing Ciamis Regency), Journal of Cakrawala Galuh Volume 1 Number December 3, 2010 the Faculty of Social and Political Sciences, University of Galuh.

[6] Solekhan, Moch. The Implementation of Village Administration, Equivalent Press: Malang, 2012. 